\title{
Influence of pulsing and wet cold storage on the vase water microbial profiles and overall quality of cut gladioli
}

\author{
Judith Kavulani Chore ${ }^{*}$ (1), Mariam Mwangi ${ }^{2}$ (ㅇ, \\ Stephen Karori Mbuthia ${ }^{1}$ (]) Lynet Ongachi Sibiyia ${ }^{3}$ (D) \\ ${ }^{1}$ Egerton University, Department of Biochemistry, Egerton, Kenya. \\ ${ }^{2}$ Egerton University, Department of Crops, Horticulture and Soils, Egerton, Kenya. \\ ${ }^{3}$ Egerton University, Department of Computer Science, Egerton, Kenya.
}

\begin{abstract}
Occlusion of the stem vasculature by microorganisms that proliferate in the vase water, or the plant vessels, leads to water stress symptoms that reduce postharvest quality of cut flowers. This study aimed to determine the effects of pulsing and wet-cold storage on the microbial profiles in cut Gladiolus grandiflorus L. cv. Fado. Pulsing treatments of 600-ppm 8-hydroxyquinoline sulfate plus $5 \%$ sucrose solution versus distilled water were administered before wet cold storage periods of $0-5$ days in cut Gladiolus, previously grown from corms under open field. A two-by-six factorial experiment embedded in a completely randomized design with four replicates was accomplished. Proc GLM in two-way Anova was adopted, and the means were separated using Tukey's test at a $5 \%$ level of significance. The pulsing treatment of $600 \mathrm{ppm} 8$-HQS plus $5 \%$ sucrose, the wet cold storage duration and their interactive effects significantly $(\mathrm{P}<0.0209 ;<0.0001$ and $<0.0001$ respectively) affected the means of the colony-forming units in the vase water of cut Gladiolus at senescence. The prolonged vase life of cut gladioli spikes was associated with decreased microbial proliferation as influenced by pulsing and wet storage duration of up to 4 days. Data generated from this study will improve existing technologies related to the quality and market value of this Gladiolus cultivar.
\end{abstract}

Keywords: Gladiolus grandiflorus; vase; 8-hydroxyquinoline; microbiota.

\section{Resumo}

Influência do pulsing e armazenamento úmido sobre os perfis microbianos e qualidade geral de gladíolo de corte O bloqueio dos vasos do xilema por microrganismos que proliferam na água de vaso ou nos vasos das plantas contribui para a redução da vida útil das flores cortadas. Este estudo teve como objetivo determinar os efeitos do pulsing e armazenamento úmido sobre os perfis microbianos de Gladiolus grandiflorus L. cv. Fado. Tratamentos de pulsing de $600 \mathrm{ppm}$ de sulfato de 8-hidroxiquinolina e sacarose $5 \%$ versus água destilada foram administrados antes do armazenamento refrigerado úmido de 0 a 5 dias em gladíolos cortados, cultivado a partir dos rizomas, em campo aberto. O experimento foi em fatorial $2 \times 6$ com delineamento inteiramente casualizado com 4 repetições. Anova Proc GLM em dois sentidos foi adotado e as médias foram separadas usando o teste de Tukey ao nível de 5\% de significância. O tratamento com pulsing de 600 ppm 8-HQS mais 5\% de sacarose e armazenamento refrigerado a úmido apresentaram efeitos interativos significativos $(\mathrm{P}<0,0209 ;<0,0001 \mathrm{e}<0,0001$ respectivamente) e afetaram as médias das unidades formadoras de colônias na água de vaso de gladíolo de corte durante a senescência. O prolongamento da vida de vaso de inflorescências de gladíolo foi associado à diminuição da proliferação microbiana, influenciada pela pulsimg e armazenamento úmido por até 4 dias. Os dados gerados a partir deste estudo irão melhorar as tecnologias existentes relacionadas à qualidade e valor de mercado desta cultivar de Gladiolus.

Palavras-chave: Gladiolus grandiflorus; vaso; 8-hidroxiquinolina; microbiota.

https://doi.org/10.1590/2447-536X.v27i4.2328

*Corresponding author: jchore@egerton.ac.ke

Received Dec 17, $2020 \mid$ Accepted May 18, 2021| Available online Aug 05, 2021

Licensed by CC BY 4.0 (https://creativecommons.org/licenses/by/4.0/)

Area Editor: Gláucia Moraes Dias 


\section{Introduction}

Occlusion by microbes and the extracellular polysaccharides that they produce is by far the most common cause of poor water relations in cut flowers (Manzoor et al., 2018; Vehniwal and Abbey, 2019). Germicides such as salts of hydroxyquinoline, aluminum sulfate, and silver nanoparticles have been employed for inhibiting bacterial proliferation in cut flowers and enhancing water uptake (Manzoor et al., 2018). The addition of probiotic bacteria to vase solution to improve the vase life of cut flowers and plants via the production of toxic metabolites, competing for nutrients, and triggering defense-response-related genes is documented (Naing et al., 2017).

The use of saccharides, such as sucrose and trehalose, prevents nuclear fragmentation thereby suppressing apoptotic cells in senescing cut flowers (Aziz et al., 2020). Not all cut flowers treated with a biocide, a carbohydrate source and acidifier solutions show improved vase life (Manzoor et al., 2018). Hence, the use of preservatives in the improvement of postharvest life of floricultural products is based on the flower species and even the cultivar under consideration (Schouten et al., 2018). Cut flowers are either transported in holding solutions (wet storage) or they are pretreated with pulsing or hydrating agents and packed as dry for storage (Senapati et al., 2016; Darras, 2020). This study focused on the role played by microbial load and diversity on the vase life of cut Gladiolus. grandiflorus cv. Fado following pulsing and wet storage. Results generated from this study showed that this cultivar improved in vase life and other quality parameters after pulsing with 600 ppm plus 5\% sucrose with subsequent wet cold storage duration of up to 4 days. These data on vase study of this cultivar could be utilized to improve the quality and market value of this Gladiolus cultivar.

\section{Material And Methods}

The gladioli plants were grown in the open field from corms between September to at a latitude of $0^{\circ} 23^{\prime} \mathrm{S}$ and longitude $35^{\circ} 35^{\prime}$ E in the Lower Highland III AgroEcological Zone (LH3) at an altitude of 2,238 $\mathrm{m}$ above the sea level. Average maximum and minimum temperatures range from 19 to $22^{\circ} \mathrm{C}$ day and 5 to $8^{\circ} \mathrm{C}$ night respectively, with a total annual rainfall of 1,200 to $1,400 \mathrm{~mm}$. Soils are predominantly mollic/andosols with a $\mathrm{pH}$ of 6.0 to 6.5 . The average room temperature used for vase study was $18^{\circ} \mathrm{C}$ with a relative humidity of $76 \%$ and $12 / 12$-hours photoperiod. In this experiment, pulsing and wet cold storage treatments' influence on the microbial profiles in vase water subsequent effect on the quality of cut Gladiolus grandiflorus $\mathrm{cv}$. Fado was investigated.

\section{Experimental design and treatment application}

Cut flowers of uniform grade of G. grandiflorus cv. Fado were harvested after 90 days from the open field of Horticulture Teaching and Research Field 3. The flower spikes were harvested when the basal two florets in the spike had shown color. The flower spikes were harvested in the morning hours (when the rate of flower metabolism is not high) and brought to the biotechnology laboratory, Egerton University, Njoro (in Nakuru County, Kenya) in a clean plastic bucket containing distilled water. The stem ends were then recut at $2 \mathrm{~cm}$ from the base with sharp and clean secateurs. Treatments employed to fresh cut flower were pulsing with sucrose $(5 \%)+8$-HQS $(600 \mathrm{ppm})$ and pulsing (in distilled water) at room temperature for 24 hours. These flowers were transferred immediately to a bucket containing distilled water and kept in a refrigerated cold storage chamber maintained at $3 \pm 1^{\circ} \mathrm{C}$, in two different sets in separate buckets. After 1, 2, 3, 4 and 5 days of storage, each of the two sets of flower treatments were brought to room temperature and compared with freshly harvested flowers (control set) for their keeping quality in distilled water in the ambient temperature. The experiment was laid in a Completely Randomized Design (CRD) with four replications.

\section{Study of vase life and quality of cut flowers}

Vase life studies and quality of non-pulsed and pulsed gladioli was done after cold storage duration of $0,1,2,3$, 4 and 5 days. Each treatment and respective cold storage interval consisted of quadruplets of five flowers. The total number of flowers in the pulsed and non-pulsed cut gladioli was 240 . These flowers were then slightly recut at the base and transferred to $1,000 \mathrm{~mL}$ plastic cylindrical vases containing distilled water, for study the vase life and quality of flowers at ambient temperature. Days taken for the basal floret to senesce was noted for the vase life study of the cut gladioli.

\section{Isolation and identification of fungi in vase water}

Both isolation and identification of fungi were done according to the modified method of Abdulla et al. (2016). Fungi from vase water of pulsed and non-pulsed Gladiolus cut flowers were isolated, quantified, and identified on zero and third days in a vase and at senescence. The vase water was transferred to sterile Petri dishes containing standard media such as potato dextrose agar (PDA) supplemented with streptomycin sulfate at the rate of three to four pieces of tissue per Petri dish and incubated at room temperature $\left(25-27^{\circ} \mathrm{C}\right.$. A portion of mycelium developing on the nutrient medium was transferred to agar slants for purification and storage for further examination. Purification of cultures of fungi in agar slants was by the hyphal tip method.

Identification and morphological characterization of the fungal pathogens were based on the sexual and asexual stage structures, hyphae, conidia, septation, concentric zone, pigmentation, fruiting bodies, various spore forms, and any other visible structures that could be observed under a compound microscope at the magnifications of 100X, 400X and 1000X. Lactophenol cotton blue was used for staining fungi for observation.

Isolation and identification of bacteria in vase water

The isolation and identification of bacteria in vase water were according to the method of Bora et al. (2016), 
but with minor modifications. Isolation of bacteria from vase water of gladioli was carried out using nutrient agar medium. Aliquots of vase water were taken on the third day of vase life and at senescence from the pulsed and non-pulsed cut flowers were diluted 100 times. Then 25 $\mu l$ aliquots of the diluted solutions were spread out on sterile nutrient agar in sterile Petri dishes. The plates were allowed to incubate at room temperature for 48 hours and individual colonies of microorganisms representing the most common morphological types were picked from the agar medium with sterile inoculating needles and streaked on eosin methylene blue (EMB) agar and mannitol salt agar media for purification. Purified microbe populations were maintained on EMB agar and mannitol salt agar for Gramnegative and Gram-positive bacteria respectively and were transferred daily on fresh media. The colonies from purified cultures were subjected to the Gram's reaction and for the study of morphological distinguishing features. Further tests used to identify the Gram-negative bacteria were as directed by biochemical tests including pigment formation (Pseudomonas species), motility, oxidase test, catalase test, $\mathrm{H}_{2} \mathrm{~S}$ production, indole test, methyl red test, VogasProskauer test, citrate utilization, starch hydrolysis and gelatin liquefaction. Bacteria were isolated and identified based on morphological features, growth on differential and selective media and biochemical tests. They were also subjected to the Vitek 2 -compact Biomereux (Model No. VK2C9938, bioMerieux) system for confirmatory identification.

\section{Data analysis}

A two-by-six factorial experiment embedded in a completely randomized design with four replicates was adopted. Pro GLM model in two way Anova was used to determine differences in pulsing and cold storage treatments on the flower microbial proliferation and vase life. Differences in means were determined using Tukey's test at 5\% level of significance. All the analyses were done using JMP software.

\section{Results And Discussion}

In this experiment, the numbers of quantified microbes were significantly different $(\mathrm{P}=\leq 0.0001)$ in vase water of Gladiolus spikes pulsed with 600 ppm 8 - HQS plus 5\% sucrose solution compared with the control (Table 1).

Table 1. Quantification of initial microbial profiles in the vase water of cut gladioli (Gladiolus grandiflorus L. cv. Fado) as affected by wet cold storage and pulsing with 600 ppm 8- HQS plus 5\% sucrose $^{\#}$.

\begin{tabular}{|c|c|c|c|c|c|c|}
\hline \multirow{2}{*}{$\begin{array}{l}\text { Days of } \\
\text { storage }\end{array}$} & \multicolumn{2}{|c|}{ Initial $\log 10 \mathrm{cfu} \mathrm{mL}^{-1}$} & \multicolumn{2}{|c|}{ Vase life (days) } & \multicolumn{2}{|c|}{ Isolates in Gladiolus vase water } \\
\hline & $\begin{array}{l}\text { Non- } \\
\text { pulsed }\end{array}$ & Pulsed & Non-pulsed & Pulsed & Non-pulsed & Pulsed \\
\hline 0 & $2.228 \mathrm{e}$ & $1.935 \mathrm{~g}$ & $4.75^{\mathrm{c}}$ & $8.75^{\mathrm{b}}$ & Aeromonas hydrophila & Proteus vulgaris \\
\hline 1 & $2.215 \mathrm{e}$ & $1.833 \mathrm{~h}$ & $9.50^{\mathrm{ab}}$ & $10.25^{\mathrm{ab}}$ & Bacillus species & Serratia marscescens \\
\hline 2 & $2.178 \mathrm{ef}$ & $1.925 \mathrm{~g}$ & $9.50^{\mathrm{ab}}$ & $10.00^{\mathrm{ab}}$ & Hafnia alvei & Staphylococcus aureus \\
\hline 3 & $1.253 \mathrm{i}$ & $2.102 \mathrm{f}$ & $9.75^{\mathrm{ab}}$ & $11.50^{\mathrm{a}}$ & Pantoea agglomerans & $\begin{array}{l}\text { Pantoea agglomerans } \\
\text { Proteus vulgaries } \\
\text { Staphylococcus species }\end{array}$ \\
\hline 4 & $2.46 \mathrm{c}$ & $2.336 \mathrm{~d}$ & $11.00^{\mathrm{ab}}$ & $11.25^{\mathrm{ab}}$ & Bacillus species & Bacillus species \\
\hline 5 & $2.734 \mathrm{~b}$ & $3.264 \mathrm{a}$ & $10.25^{\text {hi }}$ & $10.25^{\mathrm{ab}}$ & Fusarium & Staphylococcus aureus \\
\hline Means & $2.178 \mathrm{a}$ & $2.232 b$ & $9.13^{\mathrm{a}}$ & $10.33^{b}$ & & \\
\hline $\mathrm{CD}$ at $5 \%$ & 0.007 & 0.007 & 0.21 & 0.21 & & \\
\hline Pulsing (P) & \multicolumn{2}{|c|}{$<0.0001^{*}$} & \multicolumn{2}{|c|}{$0.003 *$} & & \\
\hline $\begin{array}{l}\text { Period of } \\
\text { Storage }\end{array}$ & \multicolumn{2}{|c|}{$<0.0001^{*}$} & \multicolumn{2}{|c|}{$<.0001 *$} & & \\
\hline $\begin{array}{l}\text { Treatment } \\
\times \text { Storage }\end{array}$ & \multicolumn{2}{|c|}{$<0.0001^{*}$} & \multicolumn{2}{|c|}{$0.0041^{*}$} & & \\
\hline
\end{tabular}

\#Means followed by the same letter within the same evaluation period are not significantly different according to Tukey's test at $5 \%$ confidence. The symbol $\times$ stands for interaction between the pulsing treatments and wet-cold storage durations (days) while the symbol* denotes significant difference in analysis of variance within or between treatments 
The initial microbial load from vase water of the control was higher $\left(2.22 \pm 0.007 \log 10 \mathrm{cfu} \mathrm{mL}^{-1}\right)$ and significantly different $(1.93 \pm 0.007 \log 10 \mathrm{cfu} \mathrm{mL}$ $\left.{ }^{1}\right)$ from that of $600-\mathrm{ppm} 8$-HQS plus $5 \%$ sucrose pulsed unstored spikes (Table 1). The lowered load in Gladiolus spikes pulsed with 600 ppm 8 - HQS plus 5 $\%$ sucrose solution may be responsible for enhanced vase life $(8.75 \pm 0.21$ days $)$ compared with that of the control $(4.75 \pm 0.21$ days) for unstored spikes. The microbial proliferation on the third day in the vase for the control treatment was higher $(3.387 \pm 2.028 \mathrm{log}$ cfu $\mathrm{mL}^{-1}$ ) than the unstored Gladiolus pulsed with 600 ppm 8-HQS plus 5\% sucrose whose microbial load was $3.208 \pm 2.028 \log$ cfu $\mathrm{mL}^{-1}$ (Table 2).

Table 2. Quantification of microbial profiles on the third day in the vase in cut gladioli (Gladiolus grandiflorus L. cv. Fado) as affected by wet cold storage and pulsing with 600 ppm 8 - HQS plus $5 \%$ sucrose $^{\#}$.

\begin{tabular}{|c|c|c|c|c|c|c|}
\hline \multirow{2}{*}{$\begin{array}{l}\text { Days of } \\
\text { storage }\end{array}$} & \multicolumn{2}{|c|}{$\begin{array}{c}\text { Third day in vase log } 10 \\
\text { cfu } \mathrm{mL}^{-1}\end{array}$} & \multicolumn{2}{|c|}{ Vase Life (days) } & \multicolumn{2}{|c|}{ Isolates in Gladiolus vase water } \\
\hline & Non-pulsed & Pulsed & $\begin{array}{l}\text { Non- } \\
\text { pulsed }\end{array}$ & Pulsed & Non-pulsed & Pulsed \\
\hline 0 & $3.387 \mathrm{bcd}$ & $3.208 \mathrm{~cd}$ & $4.75^{\mathrm{c}}$ & $8.75^{\mathrm{b}}$ & $\begin{array}{c}\text { Penicillium species } \\
\text { Shewanella } \\
\text { putrefaciens } \\
\text { Salmonella } \text { species } \\
\text { Vibrionaceae } \\
\text { Aeromonas hydrophila }\end{array}$ & $\begin{array}{c}\text { Pseudomonas putida } \\
\text { Pantoea agglomerans } \\
\text { Bacillus species } \\
\text { Aspergillus } \text { species } \\
\text { Ulocladium } \\
\text { Staphylococcus aureus }\end{array}$ \\
\hline 1 & $2.584 \mathrm{ef}$ & $3.539 \mathrm{bc}$ & $9.50^{\mathrm{ab}}$ & $10.25^{\mathrm{ab}}$ & $\begin{array}{l}\text { Penicillium species } \\
\text { Bacillus species } \\
\text { Serratia marscescens }\end{array}$ & $\begin{array}{l}\text { Aspergillus fumigatus } \\
\text { Serratia marscescens } \\
\text { Pantoea agglomerans }\end{array}$ \\
\hline 2 & $2.359 \mathrm{ef}$ & $2.215 \mathrm{f}$ & $9.50^{\mathrm{ab}}$ & $10.00^{\mathrm{ab}}$ & Hafnia alvei & $\begin{array}{c}\text { Albugo species } \\
\text { Aspergillus species } \\
\text { Staphylococcus aureus }\end{array}$ \\
\hline 3 & $4.696 \mathrm{a}$ & $3.251 \mathrm{bcd}$ & $9.75^{\mathrm{ab}}$ & $11.50^{\mathrm{a}}$ & $\begin{array}{c}\text { Alternaria alternata } \\
\text { Pantoea agglomerans }\end{array}$ & $\begin{array}{c}\text { Acremonium species } \\
\text { Paecilomyces } \\
\text { Phytophthora } \\
\text { Alternaria } \text { species }\end{array}$ \\
\hline 4 & $3.696 \mathrm{~b}$ & $2.637 \mathrm{e}$ & $11.00^{\mathrm{ab}}$ & $11.25^{\mathrm{ab}}$ & $\begin{array}{l}\text { Bacillus species } \\
\text { Candida albicans } \\
\text { Uromyces species }\end{array}$ & $\begin{array}{l}\text { Bacillus species } \\
\text { Cladosporium }\end{array}$ \\
\hline 5 & $3.097 \mathrm{~d}$ & $4.720 \mathrm{a}$ & $10.25^{\mathrm{hi}}$ & $10.25^{\mathrm{ab}}$ & $\begin{array}{l}\text { Fusarium } \\
\text { Exophiala }\end{array}$ & $\begin{array}{l}\text { Madurella } \\
\text { Tricothecium roseum } \\
\text { Exophiala jeanselmei } \\
\text { Staphylococcus }\end{array}$ \\
\hline Means & $3.288 \mathrm{a}$ & $3.261 \mathrm{a}$ & $9.13^{\mathrm{a}}$ & $10.33^{\mathrm{b}}$ & & \\
\hline $\mathrm{CD}$ at $5 \%$ & 2.028 & 2.028 & 0.21 & 0.21 & & \\
\hline Pulsing (P) & \multicolumn{2}{|c|}{0.5453} & \multicolumn{2}{|c|}{$0.003^{*}$} & & \\
\hline $\begin{array}{l}\text { Period of } \\
\text { Storage }\end{array}$ & \multicolumn{2}{|c|}{$<0.0001 *$} & \multicolumn{2}{|c|}{$<0.0001^{*}$} & & \\
\hline $\begin{array}{l}\text { Treatment } \\
\times \text { Storage }\end{array}$ & \multicolumn{2}{|c|}{$<0.0001 *$} & \multicolumn{2}{|c|}{$0.0041^{*}$} & & \\
\hline
\end{tabular}

"Means followed by the same letter within the same evaluation period are not significantly different according to Tukey's test at $5 \%$ confidence. The symbol $\times$ stands for interaction between the pulsing treatments and wet-cold storage durations (days) while the symbol*denotes significant difference in analysis of variance within or between treatments 
This observation is comparable to other experiments in which the biocidal influence of preservatives and pulsing agents inhibit microbial proliferation in the stems and/or vase water of many cut flower and foliage plant species (Naing et al., 2017; Wijayabandara et al.,
2018). As shown in Tables 1, 2 and 3, wet cold storage duration significantly affected microbial proliferation $(\mathrm{P}<0.0001)$ in the vase water of the spikes pulsed with $600 \mathrm{ppm} 8$-HQS plus $5 \%$ sucrose solution compared with the control.

Table 3. Quantification of Microorganisms at senescence in vase water of cut gladioli (Gladiolus grandiflorus L. cv. Fado) as affected by wet Cold storage and pulsing with $600 \mathrm{ppm} 8$ - HQS plus 5\% Sucrose

\begin{tabular}{|c|c|c|c|c|c|c|}
\hline \multirow{2}{*}{$\begin{array}{l}\text { Days of } \\
\text { storage }\end{array}$} & \multicolumn{2}{|c|}{ 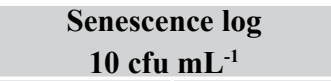 } & \multicolumn{2}{|c|}{ Vase Life (days) } & \multicolumn{2}{|c|}{ Isolates in Gladiolus vase water } \\
\hline & Non-pulsed & Pulsed & Non-pulsed & Pulsed & Non-pulsed & Pulsed \\
\hline 0 & $6.738 \mathrm{abc}$ & $6.093 \mathrm{bcde}$ & $4.75^{\mathrm{c}}$ & $8.75^{\mathrm{b}}$ & $\begin{array}{c}\text { Aspergillus niger } \\
\text { Penicillium species } \\
\text { Cladosporium oxysporum } \\
\text { Altanaria altanata } \\
\text { Aspergillus flavus }\end{array}$ & $\begin{array}{c}\text { Syncephalastrum Trichophyton } \\
\text { verrucosum } \\
\text { Epidermophyton } \\
\text { Nigrospora } \\
\text { E. nidulans, } \\
\text { Acremonium species } \\
\text { Ulocladium }\end{array}$ \\
\hline 1 & $5.579 \mathrm{def}$ & $7.255 \mathrm{a}$ & $9.50^{\mathrm{ab}}$ & $10.25^{\mathrm{ab}}$ & $\begin{array}{l}\text { Penicillium species } \\
\text { Aspergillus niger } \\
\text { Alternaria species } \\
\text { Aspergillus flavus } \\
\text { Acremonium species }\end{array}$ & $\begin{array}{l}\text { Aspergillus fumigatus } \\
\text { Rhizopus species } \\
\text { Talaromyces } \\
\text { Aspergillus parasiticus }\end{array}$ \\
\hline 2 & $6.784 \mathrm{abc}$ & $6.402 \mathrm{abcd}$ & $9.50^{\mathrm{ab}}$ & $10.00^{\mathrm{ab}}$ & $\begin{array}{l}\text { Alternaria alternate } \\
\text { Aspergillus niger } \\
\text { Alternaria species } \\
\text { Aspergillus flavus } \\
\text { Acremonium species }\end{array}$ & $\begin{array}{l}\text { Albugo species } \\
\text { Aspergillus species } \\
\text { Alternaria species }\end{array}$ \\
\hline 3 & $7.103 \mathrm{ab}$ & $5.331 \mathrm{ef}$ & $9.75^{\mathrm{ab}}$ & $11.50^{\mathrm{a}}$ & $\begin{array}{l}\text { Alternaria species } \\
\text { Aspergillus nidulans } \\
\text { Acremonium species }\end{array}$ & $\begin{array}{c}\text { Alternaria } \text { species, Acremonium } \\
\text { species } \\
\text { Phytophthora } \\
\text { Paecilomyces species }\end{array}$ \\
\hline 4 & $5.914 \mathrm{cdef}$ & $4.973 \mathrm{f}$ & $11.00^{\mathrm{ab}}$ & $11.25^{\mathrm{ab}}$ & $\begin{array}{l}\text { Candida albicans } \\
\text { Acremonium species } \\
\text { Aspergillus niger } \\
\text { Aspergillus flavus } \\
\text { Uromyces }\end{array}$ & $\begin{array}{c}\text { Rhizopus } \\
\text { Aspergillus nidulans } \\
\text { Aspergillus flavus } \\
\text { Cladosporium species }\end{array}$ \\
\hline 5 & $5.258 \mathrm{ef}$ & $5.506 \mathrm{def}$ & $10.25^{\mathrm{hi}}$ & $10.25^{\mathrm{ab}}$ & $\begin{array}{c}\text { Cephalotricum } \\
\text { Fusarium } \\
\text { Exophiala jeanselmei } \\
\text { Candida albicans } \\
\text { Tricothecium }\end{array}$ & $\begin{array}{c}\text { Tricothecium roseum } \\
\text { Exophiala jeanselmei } \\
\text { Zygomycete } \\
\text { Lichhen } \\
\text { Madurella } \text { species }\end{array}$ \\
\hline Means & $6.229 \mathrm{a}$ & $5.926 b$ & $9.13^{\mathrm{a}}$ & $10.33^{b}$ & & \\
\hline $\mathrm{CD}$ at $5 \%$ & 3.008 & 3.008 & 0.21 & 0.21 & & \\
\hline Pulsing (P) & 0.02 & & 0.00 & & & \\
\hline $\begin{array}{c}\text { Period of } \\
\text { Storage }\end{array}$ & $<0.0$ & $01 *$ & $<0.00$ & & & \\
\hline $\begin{array}{l}\text { Treatment } \\
* \text { Storage }\end{array}$ & $<0.0$ & & 0.00 & & & \\
\hline
\end{tabular}

"Means followed by the same letter within the same evaluation period are not significantly different according to Tukey's test at $5 \%$ confidence. The symbol $\times$ stands for interaction between the pulsing treatments and wet-cold storage durations (days) while the symbol* denotes significant difference in analysis of variance within or between treatments 
The interactive effect of the pulsing treatment and the cold storage duration significantly $(\mathrm{P}<0.0001)$ affected the number of colony-forming units in the Gladiolus vase water (Tables 1,2 and 3 ). The pulsing solution negatively affected the mean $\left(3.208 \pm 2.028 \log\right.$ cfu-mL $\left.L^{-1}\right)$, microbial counts, compared with the control $\left(3.387 \pm 2.028 \mathrm{cfu} \mathrm{mL}^{-}\right.$ $\left.{ }^{1}\right)$ on the third day of the vase life (Table 2). The same trend was observed on the third day of the vase life in the microbial counts from vase water of cut Gladiolus pulsed with 600 ppm $8-\mathrm{HQS}$ plus $5 \%$ sucrose solution (Table 2) and wet cold-stored for up to 4 days before display life. However, Gladiolus cut flowers subjected to 5 days' wet cold storage before vase study had higher mean microbial counts compared with the control $(4.720 \pm 2.028 \log$ cfu$\mathrm{mL}^{-1} ; 3.387 \pm 2.028 \log \mathrm{cfu} \mathrm{mL}^{-1}$ ) respectively (Table 2).

The pulsing treatment of $600 \mathrm{ppm} 8$-HQS plus $5 \%$ sucrose, the wet cold storage duration and their interactive effects significantly $(\mathrm{P}=0.020 ; \quad<0.000$ and $<0.0001$ respectively) affected the means of the colony-forming units in the vase water of cut Gladiolus at senescence (Table 3). The cut Gladiolus pulsed with 600 ppm HQS plus $5 \%$ sucrose and not stored had lower a microbial load $\left(6.093 \pm 3.008 \log\right.$ cfu- $\left.\mathrm{mL}^{-1}\right)$ in comparison with the control $\left(6.738- \pm 3.008 \log \mathrm{cfu} \mathrm{mL}^{-1}\right)$ at senescence. The same trend at senescence was observed in the mean colony-forming units in vase water of Gladiolus pulsed with $600 \mathrm{ppm}$ HQS plus $5 \%$ sucrose and wet cold-stored for 2, 3, 4 and 5 days before the study of vase life at ambient temperatures.

Spikes wet cold-stored for one day after the pulsing treatment of $600 \mathrm{ppm}$ HQS plus 5\% sucrose had a higher bacterial load $\left(7.25 \pm 3.008 \log \mathrm{cfu} \mathrm{mL}^{-1}\right)$ in comparison with that of the control $\left(6.738 \pm 3.008 \log \mathrm{cfu} \mathrm{mL}^{-1}\right)$ (Table 3, Figure 1) but still depicted a better vase life (10.25 0.21 days).
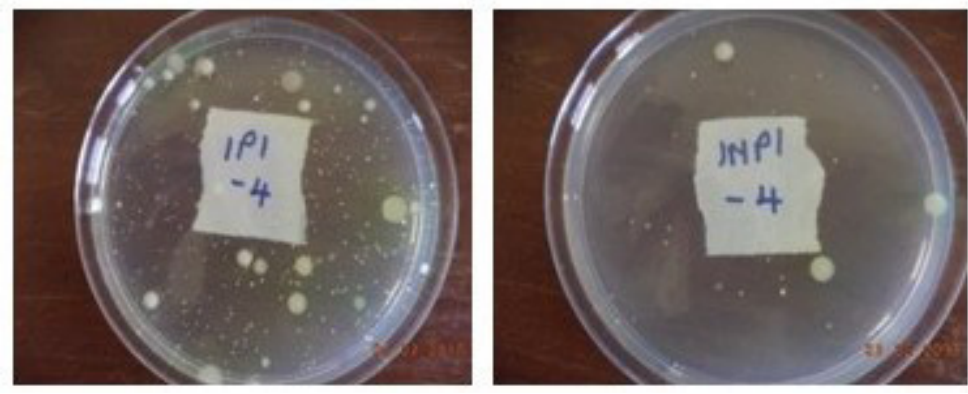

Figure 1. Colony-forming units on nutrient agar isolates at senescence from vase water of Gladiolus cold-stored for one day after pulsing with (A) 600 ppm 8-HQS plus $5 \%$ sucrose and (B) distilled water respectively.

This could imply that the rate of microbial proliferation may not be the sole deterrent factor behind the postharvest performance of cut Gladiolus grandiflorus L. cv. Fado. The use of the pulsing treatment of 600 ppm HQS plus 5\% sucrose instead of distilled water invariably increased the vase life of the cut Gladiolus compared to the control (Tables 1, 2 and 3). In this study, it was observed that irrespective of the mode of pulsing undertaken, the microbial load in spikes wet cold-stored for 5 days before vase study was invariably lower at senescence compared with the control (Table 1). This could be attributed to the inhibitory effect of lowered temperatures on microbial proliferation coupled with competition for available nutritive resources.

It is presumed that the enhanced vase life could be associated with improved keeping quality of the dual effects of HQS in enhancing water uptake and biocidal roles that minimize plant xylem vessel emboli. These results are in agreement with the work done on cut tuberose (Polianthess tuberosa L.) and Gladiolus in which keeping quality of the flowers significantly decreased as a result of cold storage without application of a preservative treatment (PérezArias et al., 2019; Chore et al., 2020).

Moreover, a study on a cut rose cv. First Red showed that the use of a carbohydrate source without a biocide increased the bacterial growth in the vase solution (Bhaskar et al., 2017). This observation is in contrast to another reported study done on a cut Gladiolus cv. American Beauty in which spikes pulsed with different concentrations of sucrose elevated their vase life. According to a study done on cut rose cvs. Akito and Grand Prix the cold storage treatment only affected stomatal opening in the former cultivar, not the latter, and it was further postulated that bacterial contamination was not related to lowered temperatures (Woltering and Paillart, 2018). A similar observation done on cut gerbera flowers showed that bacterial interactions in the postharvest life were strongly genotype-dependent. (Schouten et al., 2018).

Studies done on cut Dianthus caryophyllus L. cv. Meddei; Iris L; Alstromeria L. and Tulipa L. highlighted their ability to tolerate bacterial counts of up to $10^{8} \mathrm{cfu} \mathrm{mL}^{-1}$ which negated the postulation that wilting and shortened vase life in these cut flowers was primarily due to these microbial interactions. Microbes may have variable impacts on cut flower quality owing to the physiological, biochemical, and toxicological responses induced by them (Jowkar et al., 2017). The microbial load entities and their interaction effects may play a role in the post-harvest quality of cut flowers (Menendez and Garcia-Fraile, 2017). Other studies done on the interaction of microorganisms and cut flowers have pointed to the positive effects of isolates such as Pseudomonas putida and Enterobacter cloaca, which increased the vase life of cut carnation cv. Omea flowers (Naing et al., 2017).

The addition of probiotic bacteria to vase solution can improve the vase life of cut flowers and plants for they exert positive effects by preventing growth and proliferation 
of phytopathogens via production of toxic metabolites, competing for nutrients, and triggering defense-response - related genes (Jiménez-Gómez et al., 2017). Salts of hydroxyquinoline used as cut flower preservatives reportedly enhanced water uptake and inhibited the proliferation of microbes such as bacteria and fungi (Dung et al., 2017). A study done on the effect on the postharvest life of cut Zinnia elegans L. "Benery" Giant Wine by pure isolates of bacteria from the stems showed different results depending on the species, incidentally Escherichia coli $(E$. coli 12) and Pseudomonas fulva improving their vase life.

The $\mathrm{pH}$ (2.78) of the pulsing solution of $600 \mathrm{ppm} 8$-HQS plus $5 \%$ sucrose solution used in this study may have played a role in lowering microbial growth on the third day in the vase. Low pH (3.0-4.0) improved the vase life of some cut flowers including Rosa L and Dendranthema L. (Carlson and Dole, 2013; Abd-Allah et al., 2019). Lowered solution $\mathrm{pH}$ also improved the vase life of Rosa hybrida cv. Tereasa (Shanan, 2017). However, lowering the $\mathrm{pH}$ did not improve the vase life of cut Zinna elegans L.'Benary" Giant Wine flowers (Carlson and Dole, 2013). While not all bacteria are killed by lowered $\mathrm{pH}$ (Guan and Liu, 2020), there are other advantages associated with acidified conditions which include the prevention and repair of xylem air occlusion and promoting higher stem hydraulic conductance (Costa et al., 2015). While treatments constituting of a biocide, carbohydrate source and acidifier solutions improve the vase life of commercial cut flowers, contrary observations have been reported. A study on Alexandria and White prosperity cultivars of Gladiolus grandiflorus' portrayed different vase life results after treatment with such preservatives, a pointer to the molecular involvement aspect apart from $\mathrm{pH}$ and microbial load among others (Manzoor et al., 2018).

The highest fungal profiles were recorded at senescence from vase water of cut non-pulsed unstored Gladiolus spikes (Table 3). Unstored Gladiolus pulsed with distilled water had only five fungal species: Aspergillus niger, Penicillium species, Cladosporium oxysporum, Altanaria altanata, and Aspergillus flavus. This was in contrast with fungal isolates from unstored but 600-ppm 8-HQS plus $5 \%$ sucrose pulsed spikes, which had: Syncephalastrum (Figure 2), Trichophyton verrucosum, Epidermophyton (Figure 3), Nigrospora, E. nidulans, Acremonium species and Ulocladium (Figure 4).
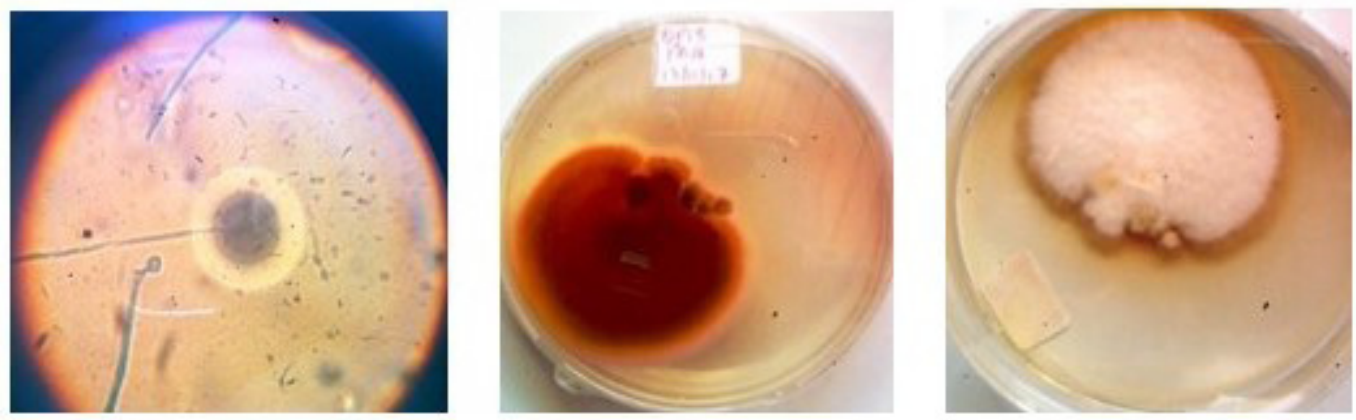

Figure 2. Syncephalastrum species with (A) microscopic appearance; (B and C) reverse and front appearance on potato dextrose agar.
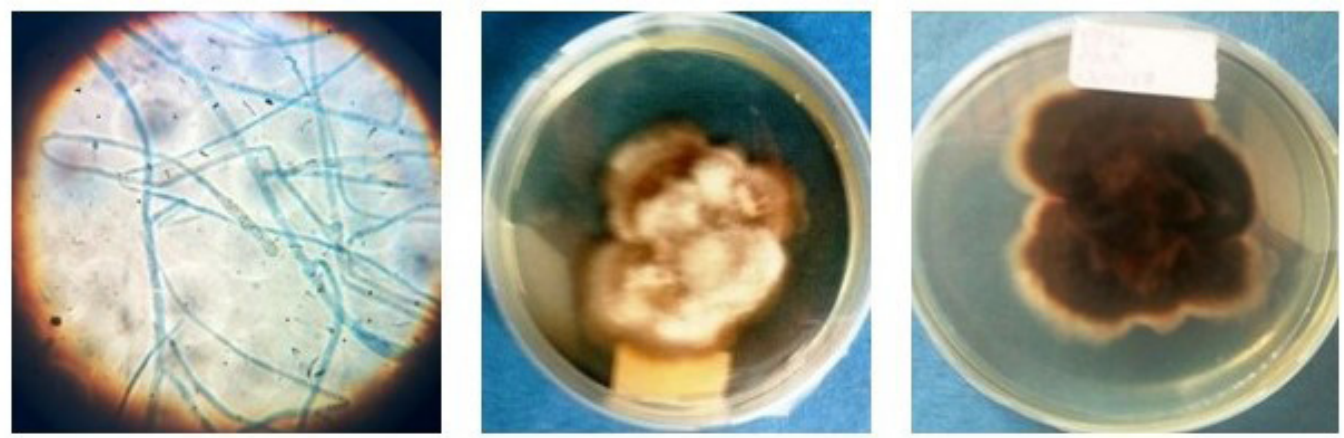

Figure 3. Epidermophyton species in which (A) is the microscopic appearance while $(\mathrm{B}$ and $\mathrm{C})$ are the reverse and front surfaces on potato dextrose agar. 

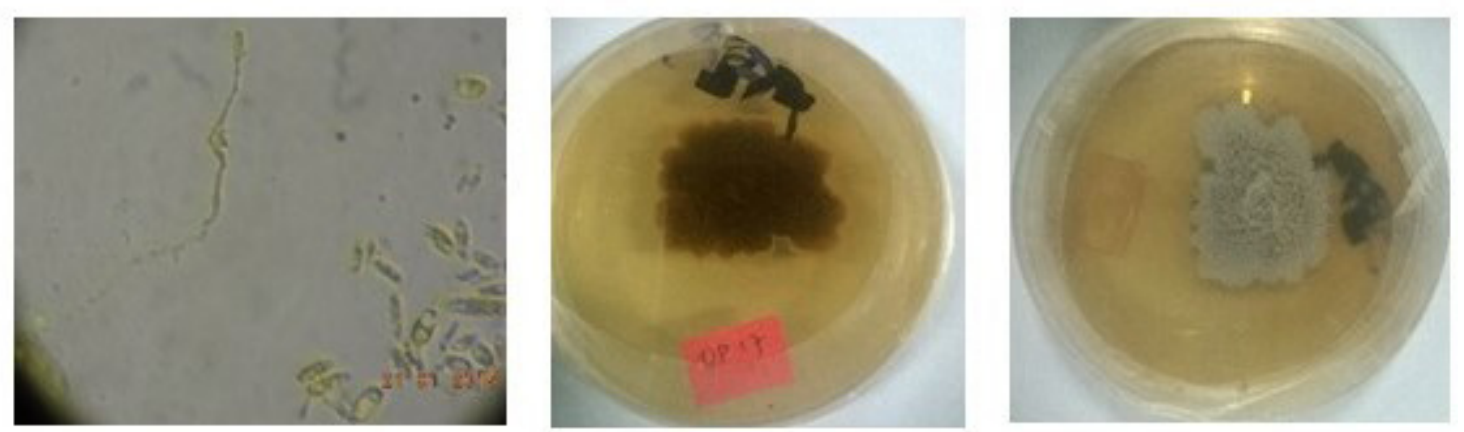

Figure 4. Ulocladium species in which (A) is the microscopic appearance while $(\mathrm{B}$ and $\mathrm{C})$ are the reverse and front surfaces on potato dextrose agar.

Subsequent storage durations of 1, 2, 3, 4 and 5 days at $3 \pm 1{ }^{\circ} \mathrm{C}$ registered comparatively less fungal isolates than the control. Many studies have implicated microbial proliferation that occasions vascular occlusion for the poor quality and water relations in cut flowers (Bhat and Sheikh, 2015). The use of a carbohydrate for energy needed in respiration together with biocides and sometimesin combination with acidifiers plus ethylene inhibitors improve the keeping quality of cut flowers (Aros et al., 2016).

The fungal species isolated from the vase water of the cut non-pulsed Gladiolus cold-stored for one day were Penicillium species, Aspergillus niger, Altanaria species, Aspergillus flavus and Acremonium species. Their counterparts pulsed with 600-ppm 8-HQS plus 5\% sucrose registered Aspergillus fumigatus, Rhizopus species, Talaromyces and Aspergillus parasiticus species. Gladiolus spikes cold-stored for two days after the pulsing treatment of distilled water had the isolates: Alternaria altanata, Aspergillus niger, Alternaria species, Aspergillus flavus and Acremonium species. Gladiolus cold stored for a similar period but pulsed with 600 -ppm 8 -HQS plus 5\% sucrose contained the isolates: Albugo species, Aspergillus species and Altanaria species in vase water at senescence. Gladiolus spikes cold-stored for three days after the pulsing with distilled water contained the isolates Alternaria species, Aspergillus nidulans and Acremonium species in the vase water at senescence. This was comparable to cut Gladiolus that had been subjected to a similar storage duration after pulsing with 600-ppm 8-HQS plus 5\% sucrose from whose vase water the isolates: Alternaria species Acremonium species, Phytophthora and Paecilomyces species were recorded (Figure 3).

Spikes cold-stored for four days after pulsing with distilled water registered the microbial isolates; Candida albicans, Acremonium species, Aspergillus niger, Aspergillus flavus and Uromyces species. Spikes pulsed with 600 ppm 8-HQS plus 5\% sucrose and cold-stored for a similar period had the isolates: Rhizopus, Aspergillus nidulans, Aspergillus flavus and Cladosporium spp. Cold storage for 5 days of cut Gladiolus spikes after the pulsing treatment with distilled water resulted in the identification of the following microbial flora: Cephalotricum, Fusarium, Exophiala jeanselmei, Candida albicans and Tricothecium. This was comparable to similarly stored spikes that were pulsed with a solution of 600 ppm HQS plus 5\% sucrose from whose water at senescence the microbial flora were Madurella, Tricothecium roseum, Exophiala jeanselmei, a Zygomycete, a Lichhen and Madurella species. The mean vase life of these cut flowers was $10.33 \pm 0.148$ days, which was significantly different $(\mathrm{P}<0.0003)$ from that of similarly stored gladioli pulsed but non-pulsed spikes whose mean was lower ( $9.5 \pm 0.148$ days) (Table 3$)$.

Prolonged storage leads to inferior keeping qualities of cut Gladiolus (Bhat and Sheikh, 2015). This trend was demonstrated on a study on Dendranthema grandiflorus Kitam, in which the cold storage of up to seven days improved the flower quality parameters (Rani and Singh, 2014). The use of 8- HQS at concentrations of 200-600 ppm has been habitually used to improve the keeping qualities of cut flowers (Senapati et al., 2016). Hydroxyquinoline sulphate has more effects on the cut flower physiology (Dung et al., 2017). Incidentally, in this study, the number of fungi isolates at senescence in gladioli pulsed with 600ppm 8-HQS plus 5\% sucrose were six. Similarly, unstored gladioli spikes pulsed with distilled water registered five different fungi species. This difference could be attributed to the role played by exogenous sucrose as a substrate for fungi (Gupta and Dubey, 2018).

Some microbes like filamentous fungi may proliferate in the presence of hydroxyquinoline sulphate due to their ability to biodegrade and transform this group of phenolic compounds whose nucleus is susceptible to chemical and structural alteration (Saadeh et al., 2020). Cold storage makes the cut flowers susceptible to microbial attacks (Pranuthi et al., 2018). Appropriate storage temperatures (4-7 ${ }^{\circ} \mathrm{C}$ for cut Gladiolus) for tropical cut flower species have been adopted for their bulking and orderly marketing (Senapati et al., 2016). However, other studies have reported the potency of 8-hydroxyquinoline as a scaffold for drug design to get novel microbial bioactive derivatives (Pippi et al., 2019). It is hypothetical that the key proteins and signal transduction pathways in plant pathogenic fungi could be the targets susceptible to preservatives such as 8-HQS in microbial inhibition (Zhang et al., 2016). The adverse effects of cold storage without pulsing of cut flowers have been reported (Chore et al., 2019).

The pulsing treatment of 8 -HQS plus $5 \%$ sucrose and the period of storage at $3 \pm 1{ }^{\circ} \mathrm{C}$ had an effect on the vase life and quality of the cut Gladiolus in this study. Adopting 
vase holding solutions with biocidal activity during vase study of the cut Gladiolus flowers could enhance the quality and vase life of the cut spikes. Also, identification of microbes by use of appropriate molecular specific tools could unravel an effective control strategy in formulating the flower preservatives to be adopted and type of mode of interactions between microbes and their effects on the subsequent flower attributes.

\section{Conclusion}

The pulsing treatment of 600 ppm 8-HQS plus 5\% sucrose decreased the microbial load in the vase water of the cut Gladiolus flowers, which reflected into enhanced vase life as a quality parameter in the pulsed wet coldstored spikes, as compared to the control.

\section{Author contribution}

KJC: Scripted the manuscript, carried out field experiments on Gladiolus propagation and laboratory isolation, enumeration and identification of microbes. MM: Experimental design and layout, sourced Gladiolus grandiflorus cv. Fado from the farmers; helped in manuscript development and proof reading. SMK: Offered guidance in the biochemical characterization of bacteria and also fungi identification. LOS: Writing - review and editing.

\section{Acknowledgements}

I wish to acknowledge Egerton University, division of research and extension for awarding funding for this study. I appreciate the input of Dr Gogo Elisha in data analysis.

\section{References}

ABD-ALLAH, A.-A.T.; MOHAMED, T.A.; MONA, A.; DARWISH, M.A.; KHENIZY, S.A.M.; TAHA, M.H. Changes in post-harvest life of cut chrysanthemum as influenced by different holding solutions and two cultivars. Middle East Journal of Agriculture Research, v.8, n.1, p.82-95, 2019.

ABDULLA, N.Q.F; GAFUR, H.F.; MUHAMED, S.R. Isolation and identification of fungi from different types of vegetables in Erbil local market. Journal of Pure and Applied Sciences, v.28, n.6, p.81-89, 2016. https://doi. org/10.21271/zjpas.v28i6.643

AROS, D.; SILVA, C.; CHAR, C.; PRAT, L.; ESCALONA, $\mathrm{V}$. Role of flower preservative solutions during postharvest of Hydrangea macrophylla cv. Bela. Journal of Agricultural Science and Research, v.43, n.3, p.418-428, 2016. https://doi.org/10.4067/S0718-16202016000300008

AZIZ, S.; YOUNIS, A.; JASKANI, M.J.; AHMAD, R. Effect of PGRs on antioxidant activity and phytochemical in delay Senescence of Lily cut flowers. Agronomy Journal, v.10, n.11, p.1704, 2020. https://doi.org/10.3390/ agronomy 10111704
BHASKAR, V.V.; RAO, P.V.; REDDY, R.S. Effect of different chemicals on the microbial growth during vase life of cut rose cv. 'First'. Journal of International Current Microbiology and Applied Science, v.6, n.10, p.812-820, 2017. https://doi.org/10.20546/ijcmas.2017.610.097

BHAT Z. A.; SHEIKH M. Q. Studies on chemical solutions and storage duration on keeping quality of cut Gladiolus (Gladiolus grandiflorus L.) spikes ('White Prosperity'). Journal of Science Research and Essays, v.10, n.24, p.655-658, https://doi.org/10.5897/SRE2015.6310015.

BORA, A.; SEERVI, K.L.; KHATRI, P.K.; SOLANKI, A.; CHANDORA, A.K.; MEENA, S.; CHANDORA, A.; RATHORE, L.; DALLA. M. Isolation of Aeromonas salmonicidia from human blood sample: A case Report. Journal of Current Microbiology and Applied Sciences, v.5, n.3, p.57-61, 2016. http://dx.doi.org/10.20546/ijcmas.2016.503.008

CARLSON, A.S.; DOLE, J.M. Postharvest water quality affects vase life of cut Dendranthema, Dianthus, Helianthus, and Zinnia. Journal of Scientia Horticulturae, v.164, p 277-286, 2013. https://doi.org/10.1016/j. scienta.2013.09.024

CHORE, K.J.; MWANGI, M.; KARORI, S.M.; KIBE, A.M. Changes in carbohydrates associated with senescence of cut Gladiolus spikes under pulsing and wet cold storage durations. African Crop Science Journal, v.28, n.Suppl.1, p.1-9, 2020. https://doi.org/10.4314/acsj.v28i1.4S

CHORE, J.K.; MWANGI, M.; MBUTHIA, S.K. Changes in total free amino acids as quality biomarkers in cut gladiolus spikes as affected by pulsing and wet cold storage. Journal of Progressive Horticulture, v.51, n.2, p.186-191, 2019. https://doi.org/10.5958/2249-5258.2019.00030.7

COSTA, L.C.; ARAÚJO, F.F.; MENDES, T.D.C.; FINGER, F. L. Influence of electrical conductivity on water uptake and vase life of cut gladiolus stems. Ornamental Horticulture, v.21, n.2, p.221-226, 2015. https://doi. org/10.14295/aohl.v21i2.673

DARRAS, A.I. Implementation of sustainable practices to ornamental plant cultivation worldwide: A critical review. Agronomy Journal, v.10, n.10, p.1570, 2020. https://doi. org/10.3390/agronomy 10101570

DUNG, C.D.; SEATON, K.; SINGH, Z. Influence of type and concentration of sugars supplemented with 8-hydroxyquinoline sulphate on the vase life of waxflower. Journal of Folia Horticulture, v.29, n.1, p.39-49, 2017. https://doi.org/10.1515/fhort-2017-0005

GUAN, N.; LIU, L. Microbial response to acid stress: mechanisms and applications. Journal of Applied Microbiology and Biotechnology, v.104, p.51-65, 2020. https://doi.org/10.1007/s00253-019-10226-1 
GUPTA, J.; DUBEY, R.K. Factors affecting post-harvest life of flower crops. Journal of International Current Microbiology Applications Science, v.7, n.1, p.548-557, 2018. https://doi.org/10.20546/ijcmas.2018.701.065

JIMÉNEZ-GÓMEZ, A.; CELADOR-LERA, L.; FRADEJAS-BAYÉN, R.; RIVAS, R. Plant probiotic bacteria enhance the quality of fruit and horticultural crops. American Institute of Mathematical Science and Microbiology Journal, v.3, n.3, p.483-501, 2017. https:// doi.org/10.3934/microbiol.2017.3.483

JOWKAR, M.; HASSANZADEH, N.; KAFI, M.; KHALIGHI, A. Comprehensive microbial study on biocide application as vase solution preservatives for cut 'Cherry Brandy' rose flower. Journal of International Horticultural Science and Technology, v.4, n.1, p.89103, 2017. https://doi.org/10.22059/ijhst.2018.213028.146

MANZOOR, A.; RAHMAN, A.; QAMAR, M.; ASHRAF, S. Evaluation of different preservative solutions and packaging material for improving post-harvest quality of gladioli (Gladiolus grandiflorus) cut spikes. Journal of World Biology and Biotechnology, v.3, n.3, p.215-222, 2018. https://doi.org/10.33865/wjb.003.03.0165

MENENDEZ, E; GARCIA-FRAILE, P. Plant probiotic bacteria: solutions to feed the world. American Institute of Mathematical Science and Microbiology Journal, v.3, n.3, p.502-524, 2017. https://doi.org/10.3934/ microbiol.2017.3.502

NAING, A.H.; WIN, N.M.; HAN, J.; LIM, K.B.; KIM, C.K. Role of nano-silver and the bacterial strain Enterobacter cloacae in increasing vase life of cut carnation 'Omea'. Journal of Frontiers in Plant Science, v.8, p.1590-1602, 2017. https://doi.org/10.3389/fpls.2017.01590

PÉREZ-ARIAS, G.A.; ALIA-TEJACAL, I.; COLINASLEÓN, M.T.; VALDEZ-AGUILAR, L.A.; PELAYOZALDÍVAR, C. Postharvest physiology and technology of the tuberose (Polianthes tuberosa L.): an ornamental flower native to Mexico. Horticulture, Environment, and Biotechnology, v.60, p.281-293, 2019. https://doi. org/10.1007/s13580-018-00122-4

PIPPI, B.; LOPES, W.; REGINATTO, P.; SILVA, F.É.K.; JOAQUIM, A.R.; ALVES, R.J.; SILVEIRA, G.P.; VAINSTEIN, M.H.; ANDRADE, S.F.; FUENTEFRIA, A.M. New insights into the mechanism of antifungal action of 8-hydroxyquinolines. Journal of Saudi Pharmaceutical, v.27, n.1, p.41-48, 2019. https://doi. org/10.1016/j.jsps.2018.07.017
PRANUTHI, P.; SUSEELA, T.; SWAMI, D.V.; SUNEETHA, S.; VANI, S.V. Effect of packing and storage conditions on physical and physiological parameters in extending the vase life of cut carnations. Journal of International Current Microbiology and Applied Science, v.7, n.8, p.1356-1364, 2018. https://doi. org/10.20546/ijcmas.2018.708.154

RANI, P.; SINGH, N. Senescence and postharvest studies of cut flowers: A Critical Review. Journal of Tropical Agricultural Science Pertanika, v.37, n.2, p.159-201, 2014.

SAADEH, H.A; SWEIDAN, K.A; MUBARAK, M.S. Recent advances in the synthesis and biological activity of 8-hydroxyquinolines. Molecules Journal, v.25, n.18, p.4321, 2020. https://doi.org/10.3390/molecules 25184321

SCHOUTEN, R.E.; VERDONK, J.C.; VAN MEETEREN, U. Re-evaluating the role of bacteria in gerbera vase life. Journal of Postharvest Biology and Technology, v.143, p.1-12, 2018. https://doi.org/10.1016/j. postharvbio.2018.04.005

SENAPATI, A.K.; RAJ, D.; JAIN, R.; PATEL, N.L. Advances in Packaging and Storage of Flowers. Journal of Commercial Horticulture, v.34, p.473-488, 2016.

SHANAN, N.T. Optimum $\mathrm{pH}$ value improving postharvest characteristics and extending vase life of Rosa hybrida cv. Tereasa cut flowers. Asian Journal of Advances in Agricultural Research, v.1, n.3, p.1-11, 2017. https://doi. org/10.9734/AJAAR/2017/34655

VEHNIWAL, S.S.; ABBEY, L. Cut flower vase life influential factors, metabolism and organic formulation. Horticulture International Journal, v.3, n.6, p.275-281, 2019. https://doi.org/10.15406/hij.2019.03.00142

WIJAYABANDARA, S.M.K.H.; DAMUNUPOLA, J.W.; KRISHNARAJAH, S.A.; DAUNDASEKERA, W.A.M.; WIJESUNDARA, D.S.A. Effect of different vase solutions on postharvest longevity of cut foliage Ophiopogon japonicas. Journal of Science Ceylon, v.47, n.2, p.195199, 2018. https://doi.org/10.4038/cjs.v47i2.7516

WOLTERING, E.J.; PAILLART, M.J.M. Effect of cold storage on stomatal functionality, water relations and flower performance in cut rose. Journal Postharvest Biology and Technology, v.136, p.66-73, 2018. https://doi. org/10.1016/j.postharvbio.2017.10.009

ZHANG, X.; JAIN, R.; LI, G. Roles of Rack1 proteins in fungal pathogenesis. Journal of Biomedical Research International, v.2016, p.17-24, 2016. https://doi. org/10.1155/2016/4130376 